\title{
A NEW SPECIES AND A NEW NAME FOR A SUBSPECIES OF CLERODENDRUM (LAMIACEAE) FROM AFRICA
}

\author{
CAREL C.H. JONGKIND \\ Nationaal Herbarium Nederland, Wageningen University branch (Herbarium Vadense), \\ Generaal Foulkesweg 37, 6703 BL Wageningen, The Netherlands \\ e-mail: Carel.Jongkind@wur.nl
}

\section{SUMMARY}

Clerodendrum atlanticum Jongkind and C. cephalanthum Oliv. subsp. occidentale Jongkind are described and illustrated.

Key words: Lamiaceae, Clerodendrum, taxonomy, Africa.

\section{INTRODUCTION}

Recently the author did collect a Clerodendrum liana in Gabon that was matching several older specimens in the herbarium identified as C. buetnerii Gürke. However, in the field it was noted that the corollas of these herbarium specimens were completely greenish white, while the corollas of the majority of the specimens identified as $C$. buetnerii did have a conspicuous red or reddish throat. Detailed comparison between specimens with different coloured corollas revealed additional differences in indumentum and flower size. It became clear that two species were involved of which the species with the completely whitish corolla was still in need of a scientific name, it is baptized here as $C$. atlanticum Jongkind. Clerodendrum buetnerii differs from the new species by its calyx that is more or less equally pilose all over the outer surface, its stamens that are 3-5 $\mathrm{cm}$ exserted and its corolla lobes that are also clearly longer than in C.atlanticum. The young parts of $C$. buetnerii are covered with conspicuous 2-3 mm long hairs, the hairs of $C$. atlanticum are shorter and less conspicuous. A third species that can be confused with the other two here mentioned is $C$. fuscum Gürke, a species with a similar large calyx and a small and straight corolla. This species differs from the other two by its leaves that are usually strongly ovate and have always a conspicuously cordate leafbase. The corolla is white with red to purple lobes, the stamens are $2-2.5 \mathrm{~cm}$ exserted and the young parts are short hairy. The whitish calyx of $C$. fuscum is usually drying lemon-yellow, in the other species the calyx changes never to yellow when drying but usually to dull-brownish. This last species is in Gabon the most commonly collected of the three. During the recent work on the Checklist of Gabon all obscure names that could possibly represent the new species were checked and rejected.

In the Flora of West Tropical Africa the new subspecies described below is mentioned as C. capitatum (Willd.) Schumach. \& Thonn. var. cephalanthum (Oliv.) Baker (Huber, 1963: 440). Verdcourt (1992: 105) more recently studied related plants from 
East Africa including the type of $C$. cephalanthum Oliv. and did come with a completely different opinion. He reinstated C. cephalanthum as a distinct species and even described several subspecies in it. At the same time he did exclude what was the West African C. capitatum var. cephalanthum sensu Huber from his C. cephalanthum (Verdcourt, 1992: 106) suggesting that it should be placed close to $C$. capitatum.

When the author studied $C$. capitatum, C. cephalanthum sensu Verdcourt and the West African material formerly named $C$. capitatum var. cephalanthum, it became clear that the last taxon had more in common with $C$. cephalanthum than with C. capitatum. Especially the shape of the inflorescence, that is characteristically capitate in $C$. capitatum but usually more elongated in $C$. cephalanthum, was important for the decision to describe a new subspecies in $C$. cephalanthum to accommodate the nameless taxon. In the Flora of Tropical East Africa the new subspecies keys out with $C$. cephalanthum because of its glabrous bracts and calyx. However, the combination of its characters is not found in any of the already described subspecies.

Clerodendrum atlanticum Jongkind, spec. nov. - Fig. 1a

Cum C. buetnerii Gürcke confuse corolla viridescenti-alba 2-2.5 cm longa. Incolit in Cameruno Gabonia. - Typus: A. Louis 79 (holo WAG; iso BR, K, LBV, MO, P), Gabon, Libreville, 10 Nov. 1982.

Liana. Leafy twigs pilose. Leaves opposite, ovate-elliptic, $4.5-15$ by $2-8 \mathrm{~cm}$, base acute to rounded, sometimes subcordate, margin entire, apex acute to acuminate, above with scattered erect hairs, beneath with erect hairs mainly on the larger nerves, punctate,
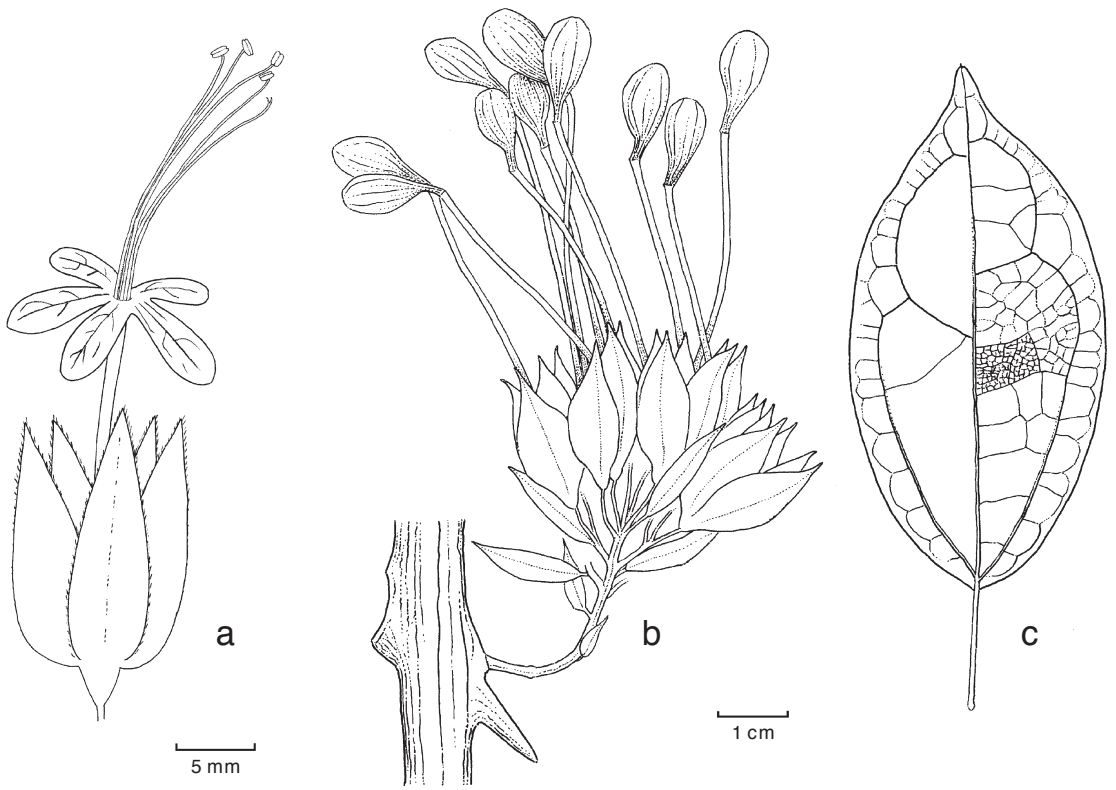

Fig. 1. a: Clerodendrum atlanticum Jongkind. Flower. - b, c: Clerodendrum cephalanthum Oliv. subsp. occidentale Jongkind. b. Inflorescence; c. leaf (a: Jongkind \& Breteler 1330; b, c: J.J. de Wilde 408; all WAG). 
4 or 5 pairs of main lateral nerves; petiole $4-25 \mathrm{~mm}$, pilose. Inflorescence axillary, umbellate-cymose, up to $10 \mathrm{~cm}$ long. Calyx campanulate, $1.5-2 \mathrm{~cm}$ long and $1 \mathrm{~cm}$ wide, lobes about two times as long as tube, green to purple-red, covered with dense short glandular hairs mixed with a few ordinary hairs on the outside but on the margin with much denser and longer hairs, glabrous inside. Corolla very pale greenish white, with glandular and ordinary hairs on the outside, tube $2-2.5 \mathrm{~cm}$ long and $1.5 \mathrm{~mm}$ in diameter, with reflexed hairs inside, lobes elliptic, c. 6 by $4 \mathrm{~mm}$, may be reflexed, glabrous inside. Stamens glabrous, $1.5-2 \mathrm{~cm}$ exserted; filaments greenish white; anthers yellow to orange-brown or dark brown, c. $2 \mathrm{~mm}$ long. Fruit not known.

Distribution - Known from only two localities, one in Cameroon and one in Gabon.

Habitat - Wet forest.

Additional material examined:

CAmeroun: Bos 3587 (K, P, WAG), 2 km S of Kribi, 8 Jan. 1969; ibid., Bos 3588 (B, BR, K, M, MO, P, PRE, UPS, WAG). - GABON: Jongkind \& Breteler 1330 (MO, WAG), Foret de la Mondah, 19 Dec. 1993; Jongkind \& Niangadouma 5896 (BR, K, LBV, MO, P, WAG), Peninsula of Cap Esterias, 8 Dec. 2003; Reitsma 2757 (WAG), Peninsula of Cap Esterias, 26 Dec. 1986.

Clerodendrum cephalanthum Oliv. subsp. occidentale Jongkind, subsp. nov. Fig. 1b, c; Map 1

A subsp. swynnertonii (S. Moore) Verdc. lobis calyces ca. $17 \mathrm{~mm}$ longa differt. Incolit in Africa occidentali aequatoriali. - Typus: J.J. de Wilde 408 (holo WAG), Côte d'Ivoire, region d'Abidjan, 23 Aug. 1956.

Clerodendrum capitatum (Willd.) Schumach. \& Thonn. var. cephalanthum (Oliv.) Baker sensu Huber in Flora of West Tropical Africa, sec. ed., part 2 (1963) 440.

Liana climbing with spine-like woody petiole-bases. Branches with hollow internodes. Leaves more or less elliptic, up to $17 \mathrm{~cm}$ long, base shortly cuneate or rounded, apex

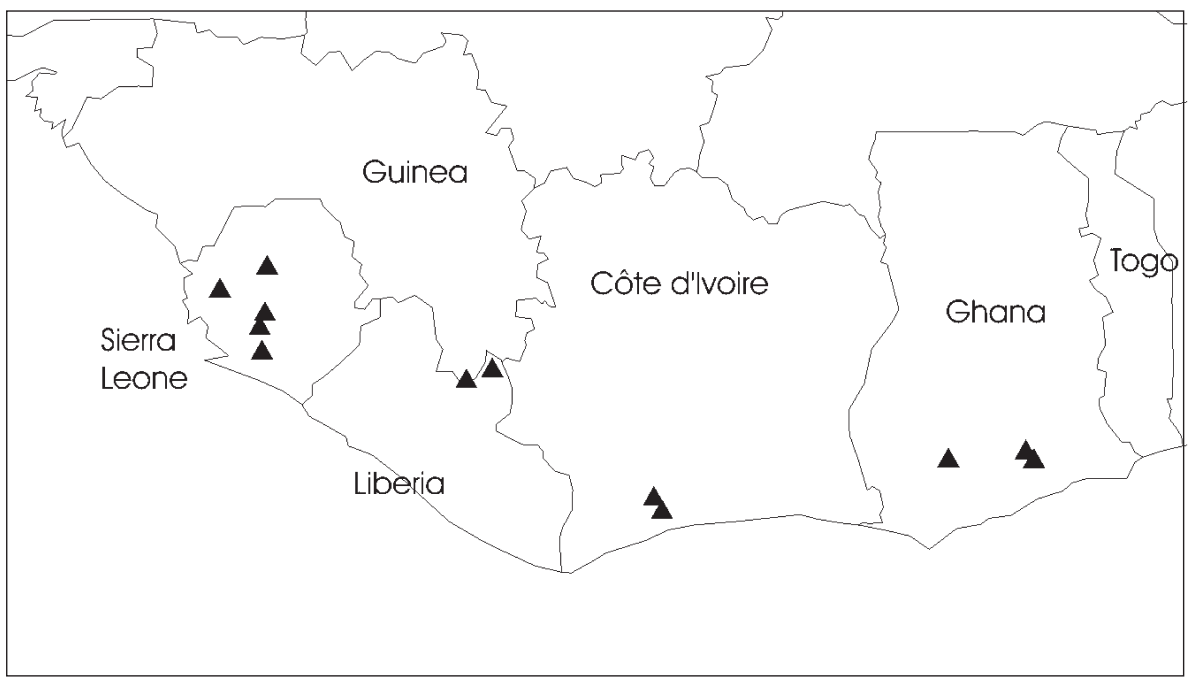

Map 1. Distribution of Clerodendrum cephalanthum Oliv. subsp. occidentale Jongkind. 
acuminate. Inflorescences shortly spicate to almost capitate, usually on short leafless side-branches, sometimes cauliflorous, almost glabrous. Calyx with scattered tiny hairs on tube and glabrous lobes, c. $22 \mathrm{~mm}$ long, lobes more than three times as long as tube, c. $8 \mathrm{~mm}$ wide, acute to acuminate. Corolla with scattered small glandular hairs and sessile glands, tube $4.5-6 \mathrm{~cm}$ long, lobes $15 \mathrm{~mm}$ long and $5 \mathrm{~mm}$ wide. Stamens c. 2 cm exserted; anthers $2.5-3 \mathrm{~mm}$ long. Fruit not known.

Distribution - Sierra Leone, Liberia, Côte d'Ivoire, Ghana.

Habitat - Forest.

Additional material examined:

Ghana: Andoh 4237 (K), Ampunyase, Aug. 1936; Deighton 3417 (K), Suhum, 3 Sept. 1937; Gyakari 510 (WAG), Atewa Range F.R., 1 Aug. 1999. - CôTE D'IVOIRE: Aké Assi 3196 (K), Baléko, 17 Sept. 1955. - LiBeria: Baldwin 9303 (K), Ganta, 17 Sept. 1947; Harley 1453 (K), Bilimi, 13 Aug. 1946. - Sierra LeONE: Deighton 3523 (K), Taiama, 18 Aug. 1938; Deighton 3790 (K), Mano, 21 Sept. 1939; Deighton 6113 (K), Gbonge (Kamagai), 3 Sept. 1954; N.W. Thomas 2296 (K), Yelaya, 23 Sept. 1914.

\section{ACKNOWLEDGEMENT}

We are grateful to Marjolein Spitteler for preparing the illustrations of C. cephalanthum subsp. occidentale.

\section{REFERENCES}

Huber, H. 1963. Clerodendrum. In: F.N. Hepper (ed.), Flora of West Tropical Africa, 2nd edition, part 2. Kew Publishing, London.

Verdcourt, B. 1992. Verbenaceae. In: R.M. Polhill (ed.), Flora of Tropical East Africa. Balkema, Rotterdam. 